\title{
Analysis of Project Based Learning Integrated with Ethno-STEM on Students' Critical and Creative Thinking Skills
}

\author{
Ariyatun \\ SMA N 1 Weleri Kendal \\ E-mail Corresponding Author: ariyatunfadzil@gmail.com
}

\begin{abstract}
Critical and creative thinking is a component of $21^{\text {st-century skills that meet the needs of }}$ the educational process. Moreover, local wisdom learning, which is closely related to scientific concepts, also needs to be emphasized. This study aimed to analyze students' critical and creative thinking skills by implementing Project-Based Learning Integrated with Ethno-STEM. This study was a case study with a One-Shot Case Study design. Its subjects were 36 students of class XI Science Program of SMA Negeri 1 (State Senior High School 1) Weleri as many as 36 students. The data collection used a test instrument validated by experts and gained a Cronbach Alpha score of 0.72 . Based on the results of data analysis, it revealed that students' critical thinking skills included good criteria with the highest achievement in the aspect of providing simple explanations. In contrast, students' creative thinking abilities belonged to good criteria with the highest achievement in flexibility, giving various interpretations of an image, story, or problem. In conclusion, Project-Based Learning integrated with Ethno-STEM can train students' critical and creative thinking skills.
\end{abstract}

Keywords: project based learning; PjBL; ethno-STEM; creative thinking; critical thinking

\begin{abstract}
Abstrak
Berpikir kritis dan kreatif merupakan komponen keterampilan abad ke-21 yang memenuhi kebutuhan dalam proses pendidikan. Selain itu pembelajaran kearifan lokal yang berkaitan erat dengan konsep keilmuan juga sangat perlu ditekankan. Penelitian ini bertujuan untuk menganalisis keterampilan berpikir kritis dan kreatif siswa melalui penerapan Project Based Learning Terintegrasi Etno-STEM. Penelitian ini adalah penelitian studi kasus dengan desain One-Shot Case Study. Subyek penelitian adalah siswa kelas XI IPA SMA Negeri 1 Weleri sebanyak 36 siswa. Pengumpulan data menggunakan instrumen tes yang telah divalidasi oleh ahli dan menunjukkan skor Alpha Cronbach 0,72. Berdasarkan hasil analisis data menunjukkan bahwa kemampuan berpikir kritis siswa termasuk dalam kriteria baik dengan capaian tertinggi pada aspek memberikan penjelasan sederhana sedangkan kemampuan berpikir kreatif siswa termasuk dakam kriteria baik dengan capaian tertinggi pada aspek flexibility yaitu memberikan bermacam-macam penafsiran terhadap suatu gambar, cerita, atau masalah. Kesimpulannya, Project Based Learning terintegrasi Etno-STEM dapat melatih keterampilan berpikir kritis dan kreatif siswa.
\end{abstract}

Kata kunci: project based learning; PjBL; Etno-STEM; berpikir kreatif; berpikir kritis 


\section{Introduction}

The Revolutionary Era 4.0 is a real challenge that the community in the nation life must face. The era of digitalization and the industrial revolution 4.0 resulted in automation in all fields, including combining real human life with the physical world fundamentally and simultaneously (Tjandrawinata, 2016). Industrial revolution 4.0 has an impact on the world of global and regional education. Educational institutions, including schools and colleges, are required to produce qualified generations who can adapt to various life challenges (Gardiner et al., 2017). One of the emphases in the current education system in Indonesia, apart from cognitive abilities, is creating a generation that can think critically and creatively (Wijayati, Sumarni \& Supanti, 2019). Higher-order thinking skills, especially critical thinking skills and creative thinking skills, are needed in utilizing students' knowledge for problem-solving and decision-making in various areas of life (Retnawati et al., 2018).

Discussions about $21^{\text {st-century skills }}$ in facing the challenges of the industrial revolution 4.0 generally refer to the core competencies of collaboration, digital literacy, critical thinking, and problemsolving in meeting the global world. Graduates must have learning skills in information communication, creative and critical thinking, and problem-solving. Therefore, it is essential to teach higherorder thinking skills which refer to competence in producing, synthesizing, and evaluating information in different cultures (Rahmawati, Ridwan \& Hadinugrahaningsih, 2019). One of the learning programs that are effective in improving critical and creative thinking skills is student-centered projectbased learning as an alternative to education to develop critical and creative thinking skills (Sasson, Yehuda \& Malkinson, 2018).

The initial observations at SMA

Negeri 1 Weleri showed that the learning carried out tended to be teacher-centered. The teaching and learning process mainly was carried out in the classroom and rarely conducted learning activities in the laboratory. Students tended to accept concepts and to be encouraged. Students were less experienced in the process of concept proof through laboratory activities. In addition, some of the assignments and test questions were not based on questions that used higher-order thinking. So, students have not been appropriately trained in solving problems in questions. The concept evaluation process was also rarely taught by teachers. The opportunity to convey ideas or creative designs in solving the problems encountered was also infrequently provided in the teaching and learning process.

The phenomenon does not only happen in Indonesia but also in other countries in the world. A study reported in Newsweek (July 10, 2010) by Bronson \& Merryman (2010) shows that the significant decline in the creativity of American students in recent decades was observed and represented as a creativity crisis. It attributes this decline to the standardization of curriculum, teaching, and assessment in schools. Students seem more pressured to memorize facts and find correct answers than critically analyzing and evaluating the content or exploring creative ideas and innovative thinking.

STEM becomes a well-known approach among educators due to the increasing perspective of $21^{\text {st-century global }}$ technology (Shernoff et al., 2017). STEM is a discipline that requires mathematics as a tool in data processing, technology, and engineering as an application of science. The STEM approach allows students to solve problems better and become innovators, inventors, independent workers, logical thinkers, and technological literacy (Afriana, Permanasari \& Fitriani, 2016). Several study results show the success of learning with a STEM approach to improve concept understanding (Utami et al., 2017) and critical thinking skills (Permanasari, 2016). Integrative STEM allows various innovative learning models that can be used to support its implementation (Oktaviani, Anom \& Lesmini, 2020). This study implemented the Project-Based Learning model integrated with Ethno-STEM (PjBL) to analyse critical and creative thinking skills. Integrating the 
Ethno-STEM approach with the PjBL model is expected to provide a solution to the existing problems. PjBL integrated with STEM is based on local culture to develop critical, creative, innovative, and collaborative thinking skills. Ethno scienceladen learning is one of the learning models that can be used to facilitate students in improving critical and creative thinking skills (Arifianawati \& Sumarni, 2016; Damayanti, Rusilowati \& Linuwih, 2017; Wibowo \& Ariyatun, 2020).

Students need to be trained to develop their experience in the Ethno-STEM field with meaningful learning to improve their knowledge and higher-order thinking skills, so Ethno-STEM integration has been carried out in PjBL learning on colloidal material. Through this PjBL learning integrated with integrated Ethno-STEM, students are expected to have hard skills balanced with soft skills and critical and creative thinking skills to develop according to competency needs in the $21^{\text {st }}$ Century. This study aimed to analyze students' critical and creative thinking skills after implementing the PjBL model integrated with Ethno-STEM in colloidal material learning.

\section{Research Method}

This study was carried out at SMA Negeri 1 Weleri with 36 class XI Science Program students as subjects. The research design used in the study was One-Shot Case Study (Creswell, 2010). In this study, the subjects were given treatment in the form of PjBL integrated with Ethno-STEM learning. After being given treatment, the subject was given a written test related to critical and creative thinking questions. The research design can be seen in table 1 .

Table 1

Research Design

\begin{tabular}{ccc}
\hline Subjects & Treatment & Critical and creative thinking skills \\
\hline XI Science Program & $\mathrm{X}$ & $\mathrm{Y}$ \\
\hline
\end{tabular}

Description:

$\mathrm{X}=$ Treatment (Implementation of PjBL Ethno-STEM)

$\mathrm{Y} \quad=$ Test after being given treatment

The data collection technique in this study was through a test technique with open-ended problem questions declared valid by two material experts and had a reliability of 0.72 . Critical and creative thinking skills were measured based on critical and creative thinking indicators adopted from (Tawil \& Liliasari, 2013). Then, the analysis of students' critical and creative thinking skills was carried out by calculating each indicator of critical and creative thinking skills from the answers to test questions. The criteria for achieving students' critical and creative thinking for each indicator were $84<\% 100$ very good categories, $68<\% 84$ good categories, $52<$ $\% 68$ good enough categories, $36<\% 52$ poor categories and \% 36 with very low category.

\section{Results and Discussion}

\section{a. Description of Activities Project Based Learning Integrated with Ethno-STEM}

STEM is an approach to link and integrate, explore, combine two or more STEM subjects into learning based on real-world problems. If the problems in life/real world are integrated with local wisdom/local culture around students, this learning is called ethnoscience integration in STEM or Ethno-STEM approach learning. Ethno science is an activity to transform/reconstruct public knowledge that has been going on for generations into scientific knowledge. Community knowledge that can be observed includes customs, habits, behavior, art, religion, language, myths, and symbols. The stages of ethnoscience 
integration in STEM learning are as follows: 1) Observing the public about community knowledge and transforming it into scientific knowledge; 2) Based on the results of the reconstruction, the chemical concepts contained in public knowledge will be identified; and 3) Based on the identification results, the integration of ethnoscience into basic competence of the selected topics is carried out, then formulating the learning target indicators and lesson plan. Next is to make a STEM analysis on the selected chemistry learning topics described in table 2.

Table 2

Analysis of STEM Learning Materials

\begin{tabular}{|c|c|}
\hline STEM Aspects & Description \\
\hline Science & $\begin{array}{l}\text { 1. Factual. Soap is a chemical compound resulting from the } \\
\text { reaction between fats or oils with bases. } \\
\text { 2. Conceptual: Saponification Reaction } \\
\text { 3. Procedural: Applying procedures to chemical reactions in } \\
\text { making herbal soaps }\end{array}$ \\
\hline Technology & $\begin{array}{l}\text { 1. Using a scale to measure/determine the mass of reagents or } \\
\text { chemicals } \\
\text { 2. Using the internet to search for information to solve the } \\
\text { problem of "good herbal soap products." } \\
\text { 3. Using computers to make reports or data analysis }\end{array}$ \\
\hline Engineering & $\begin{array}{l}\text { 1. Designing and making soap according to design } \\
\text { 2. Making herbal soaps with various aromas }\end{array}$ \\
\hline Mathematics & $\begin{array}{l}\text { 1. Calculating the composition of reagents in soap making } \\
\text { 2. Planning an effective budget }\end{array}$ \\
\hline
\end{tabular}

(Source: Adopted from Sudarmin et al., 2019))

The research of project-based learning integrated with Ethno-STEM was carried out following the general syntax. The syntax of the STEM integrated chemistry learning model through $\mathrm{PjBL}$ is described in Table 3.

In the process of project activities, each group was allowed to discuss solving problems on students' worksheets related to STEM aspects to express ideas and thoughts. In this process, students' skills were trained to be more active in finding creative ideas, digging up information, displaying work results, and providing solutions to any problems encountered.

\section{b. Analysis of Critical and Creative Thinking Skills}

The overall achievement of critical and creative thinking skills was obtained by calculating the average percentage of students who correctly answered each item. The results of the analysis of students' critical and creative thinking skills are presented in Figure 1. In contrast, the recapitulation of the achievement of each critical thinking indicator is illustrated in Figure 2. The recapitulation of the achievement of each creative thinking indicator is presented in Figure 3.

Aspects of critical thinking skills studied on this occasion including giving simple explanations, building basic skills, and concluding. Meanwhile, aspects of creative thinking skills included: flexibility, fluency, originality, elaboration, and evaluation. Figure 1 shows that the achievement of critical thinking skills as many as $52 \%$ of students are good category and $24 \%$ a very good category. While the achievement of creative thinking, $62 \%$ of students are good category, and $16 \%$ are very good category. These data show that the implementation of PjBL integrated with 
Ethno-STEM can improve students' critical and creative thinking skills. This situation is in line with Sumarni et al., (2020) research that says that STEM-PjBL learning integrated with local wisdom is very effective in improving students' critical and creative thinking skills. Based on the descriptive analysis of the obtained critical thinking ability data, the results show that the students' abilities are high and medium categories. Han et al. (2016) also conclude in their research that the score of critical thinking skills achieved by students during STEM-PjBL learning is higher than non-STEM learning. Meanwhile, Arfianawati, Sudarmin \& Sumarni (2016) also conclude that the ethnoscience approach in classroom learning can improve students' critical thinking skills. This achievement proves that the implementation of Ethno-STEM in PjBL can guide students in connecting the knowledge learned with concepts and technologies in daily life.

\section{Table 3}

Learning Syntax of PjBL Learning Integrated with Ethno-STEM

\begin{tabular}{|c|c|}
\hline Learning Syntax & Description \\
\hline $\begin{array}{c}\text { Phase } \\
\text { Engage }\end{array}$ & $\begin{array}{l}\text { 1) The teacher divided into groups (e.g., five groups). } \\
\text { 2) The teacher played a related video: Covid-19. } \\
\text { 3) The teacher asked rhetorical questions such as: "What do you observe from } \\
\text { the video related to Covid-19, why it is spreading, what should be done to } \\
\text { prevent it." } \\
\text { 4) Finding the benefits of learning the importance of soap or concepts related } \\
\text { to organic chemical reactions [saponification] } \\
\text { 5) "What should we do to avoid Covid-19?" } \\
\text { Example: Prevention of Covid-19-YouTube: https://www.youtube.com }\end{array}$ \\
\hline $\begin{array}{c}\text { Explanation } \\
\text { phase }\end{array}$ & $\begin{array}{l}\text { 1) Students presented and explained the results of group discussions regarding } \\
\text { the experimental design/project for making soap and why the herbal soap } \\
\text { was made. } \\
\text { 2) The teacher provided input from the design, both in terms of the best } \\
\text { concepts, procedures, and soap-making techniques. }\end{array}$ \\
\hline $\begin{array}{c}\text { Exploratory } \\
\text { Phase }\end{array}$ & $\begin{array}{l}\text { 1) Students collected information from various sources regarding the } \\
\text { manufacture of herbal soaps. } \\
\text { 2) The teacher distributed worksheets to each group to discuss the tools and } \\
\text { materials for making herbal soap. } \\
\text { 3) Students handed in worksheets that have been discussed } \\
\text { 4) Each group presented the results of the discussion regarding the plan to } \\
\text { make herbal soap. } \\
\text { In this activity, creative and critical thinking, collaboration, and communication } \\
\text { skills were developed }\end{array}$ \\
\hline $\begin{array}{c}\text { Elaboration } \\
\text { Phase }\end{array}$ & $\begin{array}{l}\text { 1) The teacher invited to make herbal soap according to the group } \\
\text { 2) The teacher provided peer assessment to see student activity and provide } \\
\text { guidance. } \\
\text { 3) Students packed herbal soap products and labeled them } \\
\text { 4) Students tested herbal soaps for hand washing, soap odor, softness, etc. }\end{array}$ \\
\hline $\begin{array}{c}\text { Evaluation } \\
\text { Phase }\end{array}$ & $\begin{array}{l}\text { 1) The teacher allowed students to present the experiment/project results of } \\
\text { making herbal soap. } \\
\text { 2) Students presented the results of the project and answered questions from } \\
\text { teachers/other students. } \\
\text { 3) The teacher evaluated learning activities and soap products. 4C skills were } \\
\text { developed, especially communication. }\end{array}$ \\
\hline
\end{tabular}

(Source: adopted from Sudarmin et al., 2019)) 


\section{Figure 1}

Percentage of Students' Critical and Creative Thinking Skills

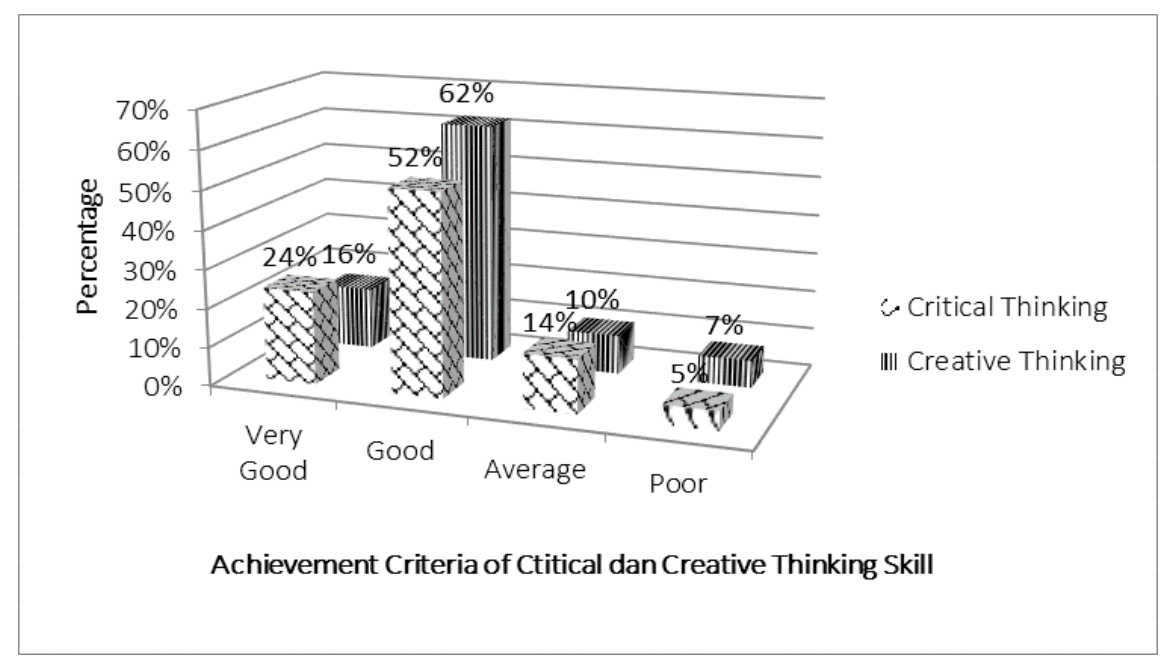

\section{Figure 2}

Average Achievement of Critical Thinking Skills

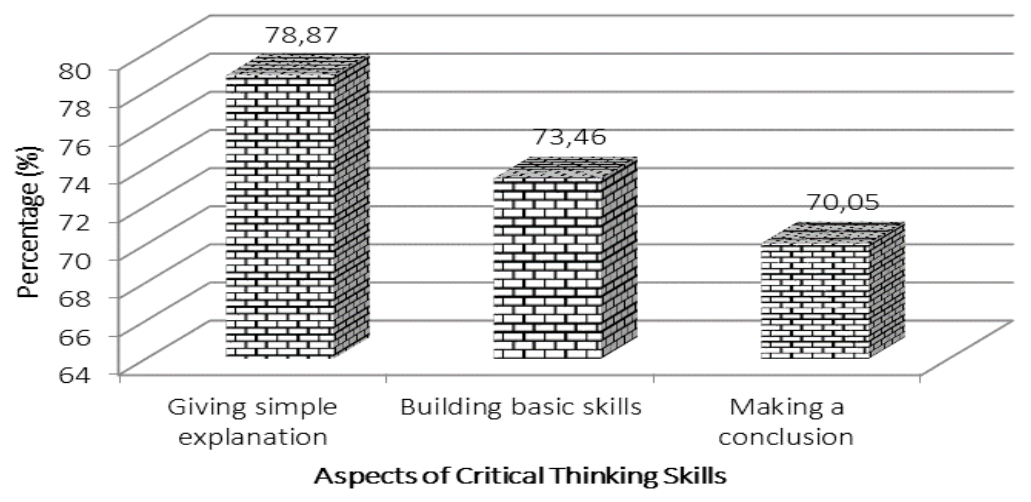

\section{Figure 3}

Average Achievement of Creative Thinking Skills



Aspects of critical thinking skills studied on this occasion including giving 40 simple explanations, building basic skills, and concluding. Meanwhile, aspects of 
creative thinking skills included: flexibility, fluency, originality, elaboration, and evaluation. Figure 1 shows that the achievement of critical thinking skills as many as $52 \%$ of students are good category and $24 \%$ a very good category. While the achievement of creative thinking, $62 \%$ of students are good category, and 16\% are very good category. These data show that the implementation of PjBL integrated with Ethno-STEM can improve students' critical and creative thinking skills. This situation is in line with Sumarni \& Kadarwati (2020) research that says that STEM-PjBL learning integrated with local wisdom is very effective in improving students' critical and creative thinking skills. Based on the descriptive analysis of the obtained critical thinking ability data, the results show that the students' abilities are high and medium categories. Han et al. (2016) also conclude in their research that the score of critical thinking skills achieved by students during STEM-PjBL learning is higher than nonSTEM learning. Meanwhile, Arfianawati, Sudarmin \& Sumarni (2016) also conclude that the ethnoscience approach in classroom learning can improve students' critical thinking skills. This achievement proves that the implementation of Ethno-STEM in PjBL can guide students in connecting the knowledge learned with concepts and technologies in daily life.

The data in figure 2 show that the critical thinking skills of students who get the highest average are providing simple explanations of 78.87, followed by aspects of building basic skills of 73.46. It is possible because the implementation of PjBL integrated with Ethno-STEM can guide students in linking the concepts learned with technology that exists in daily life. This linkage refers to concepts related to traditional technology and technology that are developed well enough so that field activities and the existing context provide the main reasons for processing good knowledge for students. Learning through Ethno-STEM PjBL reflects the process used by scientists to solve real-world problems by actively building new knowledge and developing problem-solving skills, especially those related to their local culture. In EthnoSTEM PjBL, students actively get involved with problem-solving through designing and building their knowledge. They are directly in contact with the context to positively impact a more comprehensive understanding of knowledge. This result is supported by Johnson (2014). He states that someone will show high critical thinking if they can express opinions confidently and generate ideas based on logical reasons.

While figure 3 shows that the highest average of creative thinking skills is in the aspect of flexibility, which is 80.04. The indicators in this aspect are to provide various interpretations of an image, story, or problem and consider situations that are different from those offered by others. This high achievement is because students are used to making questions and making conclusions or summaries at the end of learning or experiments during the EthnoSTEM PjBL teaching and learning process. Students are also guided in analyzing and interpreting solutions based on calculation (mathematical) data in this learning process. It makes students able to answer questions coherently and systematically. Han et al. (2014) also concluded in their research that PjBL-STEM is an appropriate learning approach in improving students' mathematical calculations. Then, the lowest percentage is in the originality aspect, with an average of 62.65. It is probably because students still find it difficult to answer the original required questions or their thoughts and knowledge in problem-solving. It is also possible because of their habit of memorizing concepts so that their level of innovation and imagination in creating new ideas is still relatively low. The concepts that students learn are not only requirements to answer questions, but students must be able to interpret, analyze, evaluate, conclude and explain in answering problems (Hughes \& Lavery, 2015). Students must connect science, technology, and mathematics in STEM-based learning (Ariyatun \& Octavianelis, 2020). Complex thinking skills also require students to be able to see and interpret specific problems comprehensively. It may be the cause of the 
low average aspect of originality of creative thinking skills in this study.

Ethno-STEM PjBL success improves learning innovations in training critical and creative thinking skills. However, further research must consider further work about students whose critical and creative thinking skills are still relatively low. Even though they show flexible thinking, students' critical and creative thinking skills are still at the stage of giving simple explanations (Sumarni \& Kadarwati, 2020).

This study has shown that students have critical and creative thinking skills. In accordance with previous research, students with high analytical abilities will have the ability to describe and connect between sections carefully to conclude appropriately (Sukmawijaya, Sukendar \& Juhanda, 2019). Although students still have to be given a longer time to practice their critical and creative thinking skills in explaining real problems, they enthusiastically participate in the learning. Tseng et al. (2013) state that this process can improve students' interest in learning, learn to be more meaningful, assist students in solving real-life problems, and support future careers. Therefore, student-centered learning should continuously be developed, and student involvement in learning should always be the main priority.

\section{Conclusion}

Based on the research results and discussion, it can be concluded that the average percentage of students' critical and creative thinking skills in the implementation of Project-Based Learning (PjBL) integrated with Ethno-STEM obtains good criteria. The highest achievement in the aspect of providing basic questions on critical thinking skills, while on creative thinking skills, the highest average percentage is found in the flexibility. It shows that if project-based learning is integrated with local wisdom and STEM aspects, it can train students to think critically and creatively. This innovative learning model can be adopted or adapted by chemistry and science teachers. Some preparation needed to make the learning process effective, basic competence analysis with STEM aspects and time management.

\section{References}

Afriana, J., Permanasari, A., \& Fitriani, A. (2016). Penerapan Project-Based Learning Terintegrasi STEM untuk Meningkatkan Literasi Sains Siswa Ditinjau dari Gender. Jurnal Inovasi Pendidikan IPA, 2(2), 202212.

Arfianawati, S., Sudarmin \& Sumarni, S. W. (2016). Model Pembelajaran Kimia Berbasis Etnosains untuk Meningkatkan Kemampuan Berpikir Kritis Siswa.Jornal Pengajaran Matematika dan Ilmu Pengetahuan Alam, 21, 46-51.

Ariyatun \& Octavianelis, D. F.. (2020). Pengaruh Model Problem Based Learning Terintegrasi STEM terhadap Kemampuan Berpikir Kritis Siswa. Journal of Educational Chemistry (JEC), 2(1), 33-39.

Bronson, P., \& Merryman, A. (2010). The Creativity Crisis. Newsweek, July 10, 2010. Retrieved on February $15,2021$.

Creswell, J.W. (2010). Research Design: Pendekatan Kualitatif, Kuantitatif, dan Mixed. Yogyakarta: Pustaka Pelajar.

Damayanti, C., Rusilowati, A., \& Linuwih, S. (2017). Pengembangan model pembelajaran ipa terintegrasi etnosains untuk meningkatkan hasil belajar dan kemampuan berpikir kreatif. Journal of Innovative Science Education, 6(1), 116-128.

Gardiner, M.O., S.I. Rahayu, M.A. Abdullah, S. Effendi, Y. Darma, T. Dartanto, \& C.D. Aruan. (2017). Era Disrupsi: Peluang dan Tantangan Pendidikan Tinggi Indonesia. Jakarta: Akademi Ilmu Pengetahuan Indonesia. 
Han, S., Capraro, R., \& Capraro, M. M. (2014). How Science, Technology, Engineering, and Mathematics (STEM) Project-Based Learning (PBL) Affects High, Middle, and Low Achievers Differently: The Impact of Student Factors on Achievement. International Journal of Science and Mathematics Education, 13(5), 1089-1113.

Han, S., Rosli, R., Capraro, M. M., \& Capraro, R. M. (2016). The Effect of Science, Technology, Engineering and Mathematics (STEM) ProjectBased Learning (PBL) on Students' Achievement in Four Mathematics Topics. Journal of Turkish Science Education, 13, 329.

Hughes, W., \& Lavery, J. (2015). Critical Thinking: An Introduction to the Basic Skills-Canadian Seventh Edition. Petersburg: Broadview Press.

Johnson, E. B. (2014). CTL: Contextual Teaching \& Learning. Bandung: Kaifa.

Oktaviani, A., Anom, K. \& Lesmini, B. (2020). Pengembangan Modul Kimia terintegrasi STEM (Science, Technology, Engineering and Mathematics) dan PBL (ProblemBased Learning). Journal of Educational Chemistry (JEC), 2 2), 64-72.

Permanasari, A. (2016). STEM Education: Inovasi dalam Pembelajaran Sains. Prosiding SNPS (Seminar Nasional Pendidikan Sains), 3, 23-34.

Rahmawati, Y., Ridwan, A., \& Hadinugrahaningsih, T. (2019, January). Developing Critical and Creative Thinking Skills Through STEAM Integration in Chemistry Learning. Journal of Physics: Conference Series, 1156(1), 012033).

Retnawati, H., Djidu, H., Apino, E., \& Anazifa, R. D. (2018). Teachers' Knowledge about Higher-Order Thinking Skills and Its Learning Strategy.
Problems of Education in the 21st Century, 76(2), 215-230.

Sasson, I., Yehuda, I., \& Malkinson, N. (2018). Fostering the Skills of Critical Thinking and Question-Posing in a Project-Based Learning Environment. Thinking Skills and Creativity, 29, 203-212.

Shernoff, D. J., Sinha, S., Bressler, D. M., \& Ginsburg, L. (2017). Assessing Teacher Education and Professional Development Needs for the Implementation of Integrated Approaches to STEM Education. International Journal of STEM Education, 4(1), 13.

Sudarmin, S., Sumarni, W., Endang, P. R. S., \& Susilogati, S. S. (2019). Implementing the Model of Project-Based Learning: Integrated with Ethno-STEM to Develop Students' Entrepreneurial Characters. Journal of Physics: Conference Series, 1317(1), 012145.

Sukmawijaya, Y., Suhendar \& Juhanda, A. (2019). Pengaruh Model Pembelajaran STEM-PjBL Terhadap Kemampuan Berpikir Kreatif Siswa pada Materi Pencemaran Lingkungan. BioEdUIN, 9(9), 28-43.

Sumarni, W., Supardi, K. I., \& Widiarti, N. (2018). Development of Assessment Instruments to Measure Critical Thinking Skills. IOP Conference Series: Materials Science and Engineering, 349(1), 012066.

Sumarni, W., \& Kadarwati, S. (2020). EthnoStem Project-Based Learning: Its Impact to Critical and Creative Thinking Skills. Jurnal Pendidikan IPA Indonesia, 9(1), 11-21.

Tawil, M. \& Liliasari. (2013). Berpikir Kompleks dan Implementasinya dalam Pembelajaran IPA. Makasar: Badan Penerbit UNM.

Tjandrawinata, R. R. (2016). Industri 4.0: Revolusi Industri Abad ini dan Pengaruhnya pada Bidang 
Kesehatan dan Bioteknologi. Jurnal Medicinus, 29(1), 31-39.

Tseng, Kuo-Hung; Chang, Chi-Cheng; Lou, Shi-Jer; Chen, Wen-Ping. (2013). Attitudes Towards Science, Technology, Engineering and Mathematics (STEM) in A Project Based Learning (PjBL) Environment. International Journal Technology and Design Education, 23, 87-102.

Utami, I. S., Septiyanto, R. F., Wibowo, F. C., \& Suryana, A. (2017). Pengembangan STEM-A (Science, Technology, Engineering,
Mathematic and Animation) Berbasis Kearifan Lokal dalam Pembelajaran Fisika. Jurnal Ilmiah Pendidikan Fisika Al-Biruni, 6(1), 67-73.

Wibowo, T. \& Ariyatun. (2020). Kemampuan Literasi Sains pada Siswa SMA Menggunakan Pembelajaran Kimia Berbasis Etnosains. Edusains, 12(2), 214-222.

Wijayati, N., Sumarni, W., \& Supanti, S. (2019). Improving Student Creative Thinking Skills Through Project-Based Learning. KnE Social Sciences, 408- 421. 